\title{
Transepithelial Transport of Epidermal Growth Factor by Absorptive Cells of Suckling Rat lleum
}

\author{
Patricia A. Gonnella, Kerry Siminoski, Richard A. Murphy, and Marian R. Neutra \\ Department of Anatomy and Cellular Biology and Harvard Digestive Diseases Center, \\ Harvard Medical School, Boston, Massachusetts 02115
}

\begin{abstract}
Epidermal growth factor (EGF), an acid-stable peptide present in rodent and human milk, is absorbed and promotes intestinal growth when fed to suckling rats. To determine whether absorptive cells of suckling rat ileum conduct selective transepithelial transport of EGF, we followed uptake of ${ }^{125}$ I-EGF from ileal loops by autoradiography and biochemical methods. Specific binding sites for ${ }^{125}$ I-EGF were localized by electron microscope autoradiography on apical membranes of ileal epithelial sheets in vitro. During uptake in vivo, radiolabeled molecules were concentrated in apical endosomal compartments and were also associated with lysosomal vacuoles, basolateral cell surfaces, and lamina propria. Excess cold EGF reduced basolateral label by 44\% and TCA precipitable serum label by $38 \%$. After 30 and 60 min of continuous uptake, radiolabeled molecules in epithelium, denuded mucosa, blood, and liver were analyzed under reducing conditions by reversed-phase high-pressure liquid chromatography (HPLC) and sodium dodecyl sulfate-polyacrylamide gel electrophoresis (SDS-PAGE). Although considerable degradation of ${ }^{125}$ I-EGF occurred after uptake from the lumen, a portion of radiolabel in epithelium and mucosa represented ${ }^{125} \mathrm{I}$ EGF which eluted somewhat more rapidly from C18 HPLC columns and showed a slight decrease in apparent molecular weight by SDS-PAGE. All radiolabel in blood and liver represented breakdown products. Thus, EGF is selectively transported across the ileal epithelium in suckling rats but is modified during transport. Milk EGF may accumulate in the lamina propria where it could influence growth and maturation of the suckling intestine.
\end{abstract}

Portions of this work were presented at the Annual Meeting of the American Society for Cell Biology, November 1984, and were published in abstract form (1984. J. Cell Biol. 99:283a.).

Address reprint requests and correspondence to Dr. Marian R. Neutra, Department of Anatomy and Cellular Biology, Harvard Medical School, 25 Shattuck Street, Boston, MA 02115.

Dr. Gonnella's current address is Department of Pediatric Gastroenterology, Children's Hospital Medical Center, Boston, MA 02115.

Dr. Siminoski's current address is St. Michael's Hospital, Toronto, Ontario, M6G 2G4 Canada.

Dr. Murphy's current address is Department of Anatomy, University of Alberta, Edmonton, Alberta, T6G 2H7 Canada.

Received for publication 5 August 1986 and in revised form 14 January 1987.

1. Abbreviations used in this paper: $\mathrm{CF}$, cationized ferritin; $\mathrm{EDB}$, epithelial dissociation buffer, EGF, epidermal growth factor; EM, electron microscope; HB, homogenization buffer; HD, half-distance; LM, light microscope; NGF, nerve growth factor; TFA, trifluoroacetic acid.

J. Clin. Invest.

(c) The American Society for Clinical Investigation, Inc.

0021-9738/87/07/0022/11 $\$ 2.00$

Volume 80 , July $1987,22-32$

\section{Introduction}

Epidermal growth factor (EGF), ${ }^{1}$ a polypeptide hormone that affects proliferation and differentiation of epithelial tissues (1, $2)$, is present in the milk of lactating mice $(3,4)$, rats $(5)$, and humans $(6,7)$. Previous investigators have shown that after oral administration of ${ }^{125} \mathrm{I}-\mathrm{EGF}$, radiolabeled molecules with EGF immunoreactivity can be recovered in blood, liver, and other tissues of suckling rats (5). Thus EGF may be absorbed from the gastrointestinal tract, but the specific sites of absorption and the mechanism by which EGF crosses the epithelial barrier are not known.

Intestinal epithelial cells of suckling rats are specialized for uptake, sorting, and digestion of milk macromolecules. In proximal regions, specific IgG receptors on luminal membranes of absorptive cells function in selective uptake of maternal immunoglobulins, intracellular sorting of IgG from soluble milk proteins, and subsequent transport of IgG to basolateral cell surfaces $(8,9)$. In the ileum, in contrast, IgG receptors have not been demonstrated; rather, ileal absorptive cells are specialized for massive endocytosis and intracellular lysosomal degradation of milk macromolecules (10-12). In previous studies, we explored the function of the complex system of endocytic compartments in ileal absorptive cells and demonstrated that membrane-bound and fluid-phase tracer macromolecules enter separate prelysosomal compartments (13). Although both adsorbed and fluid-phase tracers were generally transported to a common lysosomal destination, we also detected transcellular transport via small vesicles, a previously unrecognized pathway, when cationized ferritin was used as an adsorptive ultrastructural tracer protein. We recently demonstrated that nerve growth factor (NGF), a peptide present in milk, is transported intact across the ileal epithelium of suckling rats (14). This raised the possibility that other physiologic milk proteins such as EGF may be selectively transported to the blood stream via this pathway.

Recently, EGF receptors were demonstrated in membrane preparations enriched in microvillar vesicles from small intestines of suckling rats (15), and specific receptor-mediated binding and endocytosis of EGF was detected in isolated crypt and villus cells from suckling rat small intestine (16). Whether any of these receptors mediate transepithelial transport of the peptide has not been examined. This study was conducted to further elucidate the functions of the endocytic complex in absorptive cells of suckling rat ileum. Specifically, our goal was to determine whether luminal EGF binds to apical endocytic domains of ileal absorptive cell surfaces, whether it enters the adsorptive endocytic pathway, and whether this peptide is selectively transported across the ileal epithelium of the suckling rat.

\section{Methods}

Preparation of ${ }^{125} I-E G F$. EGF was purified from extracts of mouse submandibular glands by the method of Savage and Cohen (17) and was iodinated using chloramine $T$. The specific activity of the ${ }^{125}$ I-EGF prep- 
arations used was $\sim 37.5 \mu \mathrm{Ci} / \mu \mathrm{g}$ EGF. All injected EGF solutions contained $1 \%$ bovine serum albumin (BSA) to minimize nonspecific sticking of EGF to glassware, syringes, and tissues.

Ligated loops in vivo. Suckling Sprague-Dawley rats (10-15 d old) (Charles River Breeding Laboratories, Inc., Wilmington, MA) were anesthetized by an intraperitoneal injection of $0.1-0.2 \mathrm{ml}$ of a solution of $25 \%$ urethane in phosphate-buffered saline (PBS). An incision was made along the midline of the abdomen, a segment of distal ileum was exposed, and ligatures were passed through the mesentery without disturbing mesenteric circulation. The distal ligature, placed $3 \mathrm{~cm}$ proximal to the cecum, was tightened. A 27-gauge needle was passed through the proximal loose ligature, the ligature was tightened around the needle, and a solution of ${ }^{125} \mathrm{I}-\mathrm{EGF}$ in PBS/BSA was injected. As the needle was withdrawn, the ligature wás further tightened to form a leak-free luminal compartment. After the appropriate time interval, blood was withdrawn by cardiac puncture and the ligated loop was excised intact. The loop lumen was rinsed with PBS and either filled with fixative solution (for autoradiography) or processed for biochemical analysis as described below.

To monitor possible leakage of ${ }^{125}$ I-EGF from ligated loops into the adjacent intestinal lumen, a loop containing labeled peptide was incubated in vivo for $60 \mathrm{~min}$ and then excised intact. 10 successive $1-\mathrm{cm}$ segments from the unligated intestine both proximal and distal to the loop were also excised, and radioactivity was counted. Significant radioactivity was detected only in segments $1-3$ on either side of the loop, indicating that luminal EGF was confined to ileum in these experiments, and did not enter jejunum or colon. In separate studies (13) we showed that the ligation procedure used here did not result in leakage of horseradish peroxidase or ferritin through epithelial tight junctions.

Fixation, tissue processing, and autoradiography. Ileal tissues and epithelia were fixed in a solution consisting of $2 \%$ freshly depolymerized formaldehyde, $2.5 \%$ glutaraldehyde, and $4 \mathrm{mM} \mathrm{CaCl}_{2}$ in $0.1 \mathrm{M}$ sodium cacodylate buffer, $\mathrm{pH}$ 7.4. Fixative-filled ileal loops were immersed in fresh fixative and sliced at $0.5 \mathrm{~mm}$. After 2-4 h of fixation at room temperature, slices were rinsed in $0.1 \mathrm{M}$ cacodylate buffer at $4^{\circ} \mathrm{C}$, postfixed in $1 \%$ osmium in cacodylate buffer, stained en bloc in $1 \%$ uranyl acetate, dehydrated in graded ethanols, and embedded in Epon-Araldite. Epithelial samples were processed in the same solutions in microfuge tubes and pelleted in Epon-Araldite. For light microscopic autoradiography, $1-\mu \mathrm{m}$ sections were stained with iron hematoxylin, coated with Ilford L4 or K5 emulsion (diluted 1:1 with distilled water), exposed for 1-4 wk, and developed for $4 \mathrm{~min}$ in Kodak D-19 at $18^{\circ} \mathrm{C}$. For electron microscope (EM) autoradiography, thin sections were collected on formvar-coated nickel grids and stained with lead citrate. Grids were carbon coated, placed on a glass slide, and coated with a thin film of Ilford L4 emulsion (diluted 1:4 with distilled water) by the loop method (18). The emulsion coat consisted of a monolayer of silver halide crystals as confirmed by electron microscopy of undeveloped grids. After 6-8 wk, autoradiographs were developed in Kodak D-19 (diluted 1:9) for $45 \mathrm{~s}$ at $18^{\circ} \mathrm{C}$ and were fixed in $24 \%$ sodium thiosulfate for $3 \mathrm{~min}$ at $18^{\circ} \mathrm{C}$. Sections were examined and photographed with a JEOL $100 \mathrm{CX}$ electron microscope.

Uptake of ${ }^{125}$ I-EGF in vivo. To follow uptake of ${ }^{125}$ I-EGF by light microscope (LM) autoradiography, we injected $100 \mu \mathrm{l}$ of PBS/BSA containing $100 \mathrm{ng}{ }^{125} \mathrm{I}$-EGF $\left(8.3 \times 10^{6} \mathrm{cpm}\right)$ into a $5-\mathrm{cm}$ ileal loop in each of four 13-d-old rat pups. After 5, 20, 60, and $120 \mathrm{~min}$, blood was collected and the loop was excised, rinsed, and fixed. For EM autoradiography, $200 \mu$ l of PBS/BSA containing $100 \mathrm{ng}{ }^{125}$ I-EGF $\left(8.3 \times 10^{6} \mathrm{cpm}\right)$ was injected into a 3-cm loop in each of three 12-d-old pups. Blood was collected and the loop excised, rinsed, and fixed after 20,60 , or $120 \mathrm{~min}$ of continuous uptake.

The presence of ${ }^{125}$ I-EGF in endocytic pathways of absorptive cells was assessed in EM autoradiographs. For each time interval, 15 welloriented cells sectioned along a central longitudinal axis were selected, and all grains over these cells were counted. Most grains were located entirely over large, readily demarcated compartments and were assigned accordingly to microvilli, apical endocytic complex, giant vacuole, nucleus, or basal cytoplasm. Grains were assigned to lateral or basal membranes if they spanned the membrane or lay within $900 \mathrm{~nm}$, the estimated half-distance (HD) for Ilford L4 emulsion exposed by ${ }^{125}$ I and processed as in this study (19).

Relative surface densities of cell compartments were calculated from the same sections by outlining compartment boundaries, overlaying a standard grid, and scoring the locations of all grid intersects (20). These values were used to calculate the relative grain density in each compartment (21). The "apical endocytic complex" includes deep invaginations of apical plasma membrane, endosomal tubules, and endosomal vesicles. Because of the close packing of these membranes and the intervening cytoplasm, the entire area was considered a single compartment for grain counts. The resolution of the method did not allow us to distinguish radiolabel associated with membranes or lumens from possible radiolabel in the adjacent cytosol. Because EGF in endosomes should be largely intact and there is no evidence for passage of EGF through endosome membranes, we assumed that most radiolabel in this area was within membrane compartments. The basolateral membrane compartment was defined by drawing a "corridor" 2 HD wide that spanned the basolateral cell surface. We recognize that longitudinal sections through polarized cells do not provide a true random sample of cellular compartments, because structures along the central axis are overrepresented in such sections. Nevertheless, this method allowed us to accurately assess relative densities of label in subcellular compartments of these polarized cell monolayers.

Specificity of ${ }^{125}$ I-EGF uptake. To compare uptake of ${ }^{125}$ I-EGF to that of free ${ }^{125} \mathrm{I}$, we injected $250 \mu \mathrm{l}$ of PBS/BSA containing $200 \mathrm{ng}$ of ${ }^{125}$ I-EGF $\left(16.6 \times 10^{6} \mathrm{cpm}\right)$ into loops in each of four 15-d-old rat pups. Loops averaged $18 \mathrm{~cm}$ in length and included the entire ileum from jejuno-ileal junction to ileo-cecal valve. Three other pups received 250 $\mu \mathrm{l}$ of a solution containing $9.5 \times 10^{6} \mathrm{cpm}$ of free ${ }^{125} \mathrm{I}$ in similar loops. Blood samples were collected from one pup of each group after 3,20, and $60 \mathrm{~min}$ of continuous uptake. (Two pups were sampled after $3 \mathrm{~min}$ of ${ }^{125}$ I-EGF uptake.) Loops were then excised and their exact lengths recorded so that levels of serum radiolabel could be corrected for loop length. Blood samples were allowed to clot and serum was collected. Radioactivity was counted in standard volumes of serum and in TCA precipitates of standard volumes.

To test the effect of unlabeled EGF on the uptake of ${ }^{125}$ I-EGF in vivo, we injected $50 \mu \mathrm{l}$ of PBS/BSA containing $50 \mathrm{ng}{ }^{125}$ I-EGF (4.15 $\times 10^{6} \mathrm{cpm}$ ) into a 3-cm loop in each of two 15 -d-old pups. One of the loops also received $50 \mu \mathrm{g}$ of unlabeled EGF (a 1,000-fold excess). After 60 min of continuous uptake, blood was collected from both pups (competed and noncompeted) and the loops were excised, rinsed, fixed, and processed for LM autoradiography. Total radioactivity in standard volumes of serum samples and TCA precipitates of these samples was counted. Paired LM autoradiographs were photographed, and for each sample three segments of well-oriented epithelium were selected that included a total of 43 cells per sample. Three major areas were demarcated as shown in Fig. 1: apical (including microvilli and endocytic complex), vacuolar (consisting largely of lysosomal vacuoles and intervening lateral cell surfaces), and basal (including nuclei, basal cytoplasm, and basolateral cell surfaces). All epithelium-associated grains were assigned to one of these compartments, and relative distributions were calculated as the percent of the total within each sample.

${ }^{125}$ I-EGF binding to isolated ileal epithelium. To visualize the distribution of specific EGF binding sites on epithelial cell surfaces, we isolated intact epithelial sheets devoid of basal lamina from the ileum of 15-d-old pups by intravascular EDTA perfusion according to the method of Bjerknes and Cheng (22), as modified by Phillips et al. (23). Samples of isolated epithelium were either transferred to Hanks' balanced salt solution (HBSS) containing $20 \mathrm{mM}$ Hepes buffer at $4^{\circ} \mathrm{C}$, or were fixed for $15 \mathrm{~min}$ in $1.5 \%$ glutaraldehyde in $0.1 \mathrm{M}$ cacodylate buffer at $23^{\circ} \mathrm{C}$. Fixed tissues were briefly rinsed in cacodylate buffer, incubated in HBSS/Hepes containing $0.1 \mathrm{M}$ glycine for $15 \mathrm{~min}$ at $23^{\circ} \mathrm{C}$ to block free aldehyde sites, and rinsed extensively in HBSS/Hepes (without glycine) at $4^{\circ} \mathrm{C}$. Fixed and unfixed epithelia were then immersed in PBS containing ${ }^{125}$ I-EGF $\left(1 \mu \mathrm{g} / \mathrm{ml}, 83 \times 10^{6} \mathrm{cpm} / \mathrm{ml}\right)$ at $4^{\circ} \mathrm{C}$ for $30 \mathrm{~min}$, rinsed in cold PBS, and fixed. Control epithelial sheets were exposed to $100 \mu \mathrm{g} / \mathrm{ml}$ cold EGF before and during incubation with ${ }^{125} \mathrm{I}-\mathrm{EGF}$. All 


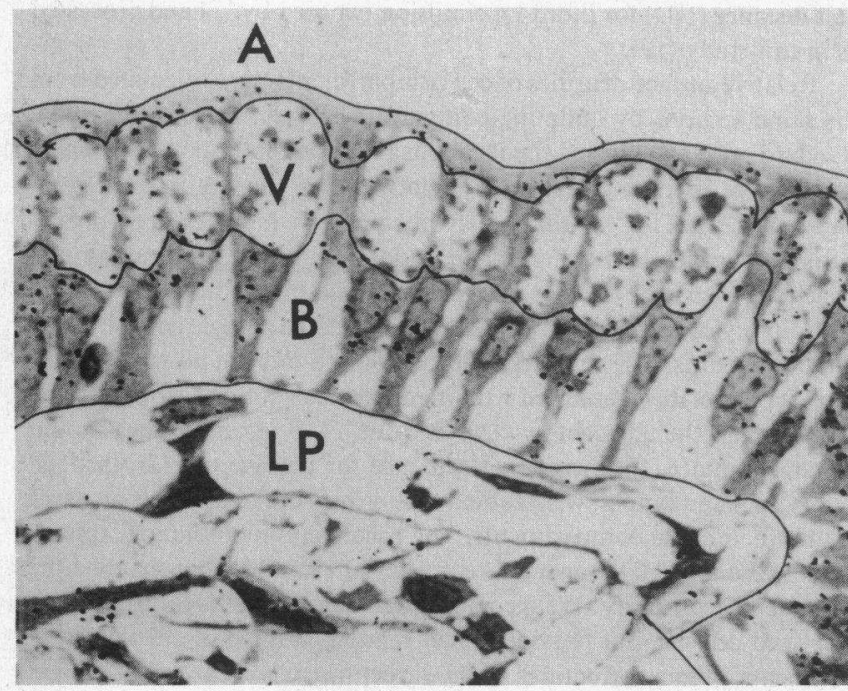

Figure 1. LM autoradiograph of villus epithelium, fixed after $60 \mathrm{~min}$ of continuous uptake of ${ }^{125} \mathrm{I}$-EGF. Major compartments were demarcated-apical $(A)$, vacuolar $(V)$, and basal $(B)$ - to estimate relative amounts of label in regions involved in uptake $(A)$, degradation $(V)$, and transepithelial transport $(B)$. In the presence of excess unlabeled EGF, relative amounts of label in the basal compartment were reduced by $44 \%$.

epithelia were then rinsed in PBS at $4^{\circ} \mathrm{C}$, fixed at $4^{\circ} \mathrm{C}$ for $30 \mathrm{~min}$, and further fixed at $23^{\circ} \mathrm{C}$ for $2 \mathrm{~h}$.

Isolated epithelia that were incubated without light prefixation showed significant degenerative changes after $60 \mathrm{~min}$ at $4^{\circ} \mathrm{C}$ in vitro, as we have observed in previous studies using similar preparations (23). Little or no binding of ${ }^{125} \mathrm{I}$-EGF to surfaces of intact cells in unfixed preparations was observed after $30 \mathrm{~min}$ at $4^{\circ} \mathrm{C}$. In contrast, epithelia that were briefly fixed before ${ }^{125}$ I-EGF binding were morphologically well preserved and showed cell surface label; these preparations were analyzed by EM autoradiography. Binding of radiolabeled EGF to apical and basolateral cell membranes of isolated epithelia was assessed by counting total plasma membrane-associated silver grains in a standard length $(100 \mu \mathrm{m})$ of epithelium in EM autoradiographs. The standard length was obtained by pooling random short lengths of well-oriented epithelial regions.

Analysis of radiolabeled molecules. To determine what portion, if any, of the ${ }^{125}$ I-EGF remained intact during and after epithelial uptake and transport, we analyzed radioactive molecules in tissue samples by high-pressure liquid chromatography (HPLC) and sodium dodecyl sulfate-polyacrylamide gel electrophoresis (SDS-PAGE). Two rat pups, 14 $\mathrm{d}$ of age, received $100 \mu \mathrm{l}$ of PBS/BSA containing $2.5 \mu \mathrm{g}$ EGF $\left(2 \times 10^{5}\right.$ $\mathrm{cpm}$ ) in $15-\mathrm{cm}$ ileal loops. After 30 and $60 \mathrm{~min}$ of continuous uptake, $0.5 \mathrm{ml}$ of cardiac blood was collected, the entire liver was excised, and the ligated loop was removed intact. Blood was mixed with an equal volume of homogenization buffer (HB), consisting of $0.1 \mathrm{M}$ phosphate buffer containing protease inhibitors $(0.5 \mathrm{mM}$ phenylmethylsulfonyl fluoride, $1 \mu \mathrm{g} / \mathrm{ml}$ aprotinin, $2 \mu \mathrm{g} / \mathrm{ml}$ antipain, and $2 \mu \mathrm{g} / \mathrm{ml}$ leupeptin), and frozen on dry ice. A liver extract was prepared in a dounce homogenizer containing $1 \mathrm{ml}$ of the same buffer and frozen. To separate epithelium from mucosa, the ileal loop was flushed with $10 \mathrm{ml}$ of ice-cold PBS and cut into three segments. Each 5-cm segment was everted on a wooden rod, washed in two changes of cold PBS for $5 \mathrm{~min}$, and immersed in epithelial dissociation buffer (EDB) for $10 \mathrm{~min}$ at $4^{\circ} \mathrm{C}$. EDB consisted of $200 \mathrm{mM}$ sucrose, $76 \mathrm{mM} \mathrm{Na}_{2} \mathrm{HPO}_{4}, 19 \mathrm{mM} \mathrm{KH}_{2} \mathrm{PO}_{4}, 60 \mathrm{mM} \mathrm{NaCl}$, and $20 \mathrm{mM}$ EDTA with protease inhibitors. Everted segments were then transferred to $10 \mathrm{ml}$ of fresh EDB and shaken. Epithelia are selectively removed by this procedure, leaving basal lamina and lamina propria intact (22). Denuded mucosa was scraped into $1 \mathrm{ml}$ of $\mathrm{HB}$, homogenized, and frozen. Epithelia were pelleted, resuspended in $1 \mathrm{ml} \mathrm{HB}$, and also homogenized and frozen.

Reversed-phase HPLC was performed on a C18 Bondapack column (Waters Instruments, Inc., Rochester, MN) equilibrated in $0.1 \%$ trifluoroacetic acid (TFA) with $21 \%$ acetonitrile. Samples (epithelium, mucosa, or liver extracts, and serum) were diluted 1:1 with starting solvent, applied to a $7.8 \times 30-\mathrm{cm}$ column, and the column was washed for 5 $\mathrm{min}$ in the same solvent. Material was eluted with a 20 -min acetonitrile gradient $(21-63 \%)$ in $0.1 \%$ TFA. Flow rate was $2 \mathrm{ml} / \mathrm{min}$. Fractions $(0.2$
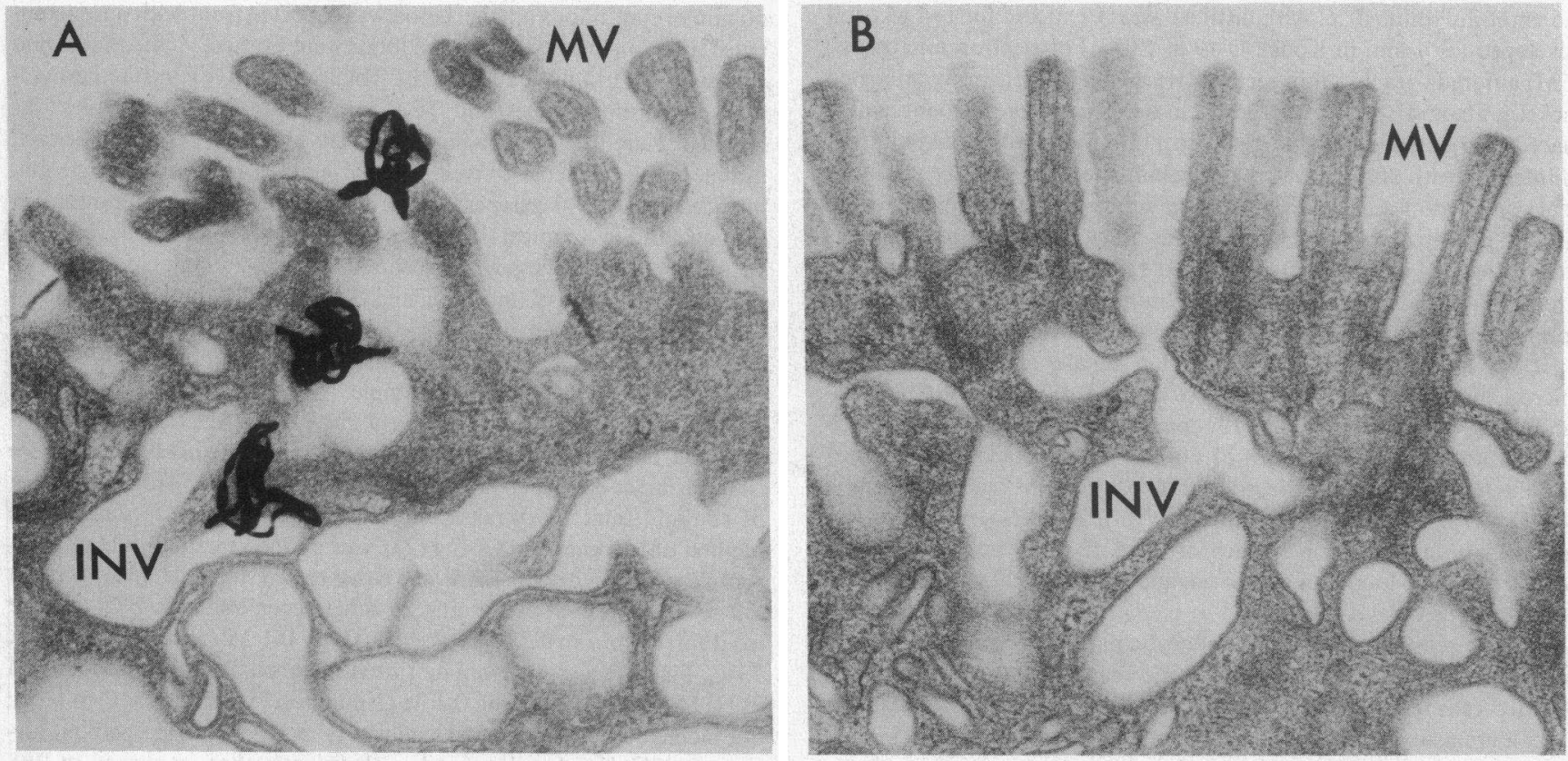

Figure 2. EM autoradiographs of apical borders of representative absorptive cells in isolated epithelial samples exposed in vitro to ${ }^{125} \mathrm{I}$-EGF at $4{ }^{\circ} \mathrm{C}$. $(A)$ Microvilli $(M V)$ and deep invaginations of apical plasma membrane $(I N V)$ are labeled but internal compartments are not. (B) In the presence of 100 -fold unlabeled EGF the number of apical silver grains was reduced by $80 \%$ and no label was detected on many cells, as shown here. 


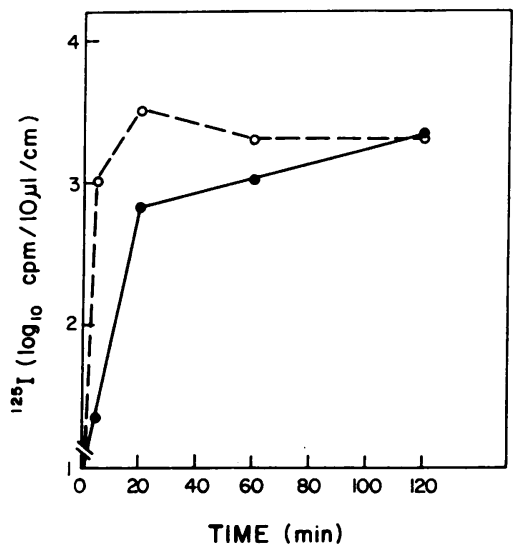

Figure 3. Appearance of radiolabel in serum during uptake of ${ }^{125} \mathrm{I}$-EGF and free ${ }^{125}$ I from ileal loops. Free ${ }^{125}$ I was rapidly transported into blood during the first 20 min of uptake, but blood levels did not increase thereafter. A portion of radiolabel from ${ }^{125}$ I-EGF also appeared in blood rapidly, but this was followed by a gradual increase from 20 to $120 \mathrm{~min}$

or $0.5 \mathrm{~min}$ ) were collected, and radioactivity in each was measured in a gamma scintillation counter (75\% efficiency; Packard Instrument Co., Inc., Downers Grove, IL).

For SDS-PAGE, samples of serum and extracts of epithelium, denuded mucosa, and liver were precipitated with $20 \%$ TCA, washed twice in acetone, and solubilized in sample buffer containing SDS and mercaptoethanol. Aliquots containing 2,000 cpm were applied to $13-22 \%$ polyacrylamide gels along with $2,000 \mathrm{cpm}$ of stock ${ }^{125}$ I-EGF. Gels were stained with Coomassie Blue, dried, autoradiographed by exposure to XAR5 film (Eastman Kodak Co., Rochester, NY) with a Cronex LightingPlus intensifying screen (DuPont Co., Wilmington, DE) at $-80^{\circ} \mathrm{C}$, and developed after $7 \mathrm{~d}$.

\section{Results}

Specificity of ${ }^{125}$ I-EGF binding, uptake, and transport. The presence and distribution of ${ }^{125}$ I-EGF binding sites on plasma membranes of ileal absorptive cells were assessed by briefly exposing fixed isolated epithelial sheets to ${ }^{125}$ I-EGF at $4^{\circ} \mathrm{C}$, in the presence or absence of excess (100-fold) unlabeled EGF. EM autoradiographs showed that ${ }^{125}$ I-EGF bound to both the microvillar and invaginated domains of villus cell apical membranes (Fig. $2 \mathrm{~A}$ ) and also to basolateral membranes. In the presence of competing unlabeled peptide, binding was reduced by $80 \%$ on apical surfaces (Fig. $2 \mathrm{~B}$ ) and by $76 \%$ on basolateral surfaces (not shown).
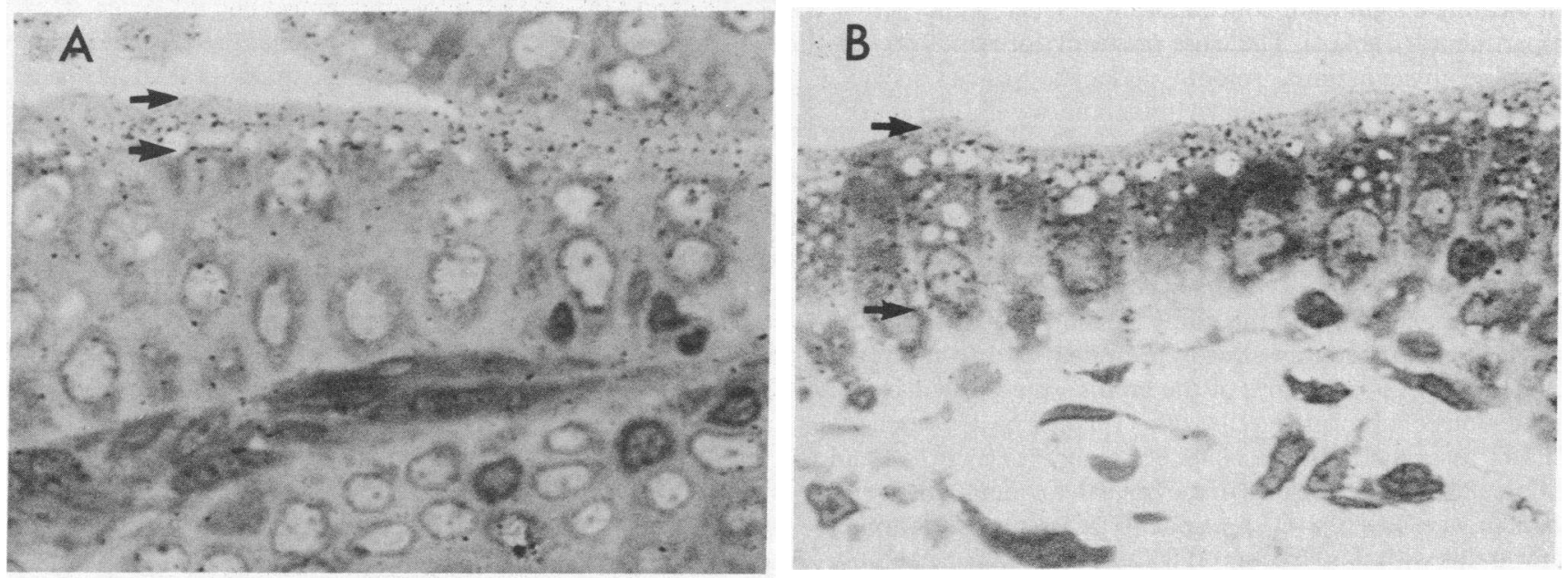

Figure 4. LM autoradiographs of villus epithelium fixed after either $5 \mathrm{~min}(A)$ or $20 \mathrm{~min}(B)$ of continuous uptake of ${ }^{125}$ I-EGF from ileal loops in vivo. $(A)$ At $5 \mathrm{~min}$, radiolabel retained by fixation is confined to luminal cell borders (arrows), a region including microvilli and apical portions of the endocytic complex. (B) By $20 \mathrm{~min}$, radiolabel is present in apical regions and also in deeper regions of epithelial cells (arrows). 


\begin{tabular}{|c|c|c|c|c|c|c|c|}
\hline \multirow[b]{3}{*}{ Cellular compartment } & \multirow[b]{3}{*}{ Relative volume } & \multicolumn{6}{|c|}{ Autoradiographic grain distribution } \\
\hline & & \multicolumn{2}{|l|}{$20 \mathrm{~min}$} & \multicolumn{2}{|l|}{$60 \mathrm{~min}$} & \multicolumn{2}{|l|}{$120 \mathrm{~min}$} \\
\hline & & Grains & $\begin{array}{l}\text { Relative grain } \\
\text { density }\end{array}$ & Grains & $\begin{array}{l}\text { Relative grain } \\
\text { density }\end{array}$ & Grains & $\begin{array}{l}\text { Relative grain } \\
\text { density }\end{array}$ \\
\hline & $\%$ & $\%$ & & $\%$ & & $\%$ & \\
\hline Microvilli & 7.3 & 14 & 1.9 & 10.5 & 1.4 & 14 & 1.9 \\
\hline Endocytic complex & 13.9 & 33 & 2.4 & 44.5 & 3.2 & 28 & 2.0 \\
\hline Giant Vacuole & 44.8 & 20 & 0.4 & 22.5 & 0.5 & 24 & 0.5 \\
\hline Golgi complex & 1.1 & 0 & 0 & 0.5 & 0.5 & 0.5 & 0.5 \\
\hline Nucleus & 8.7 & 6 & 0.7 & 4 & 0.5 & 8 & 0.9 \\
\hline Basal cytoplasm & 7.5 & 12 & 1.6 & 4 & 0.5 & 11.5 & 1.5 \\
\hline Basolateral membrane & 16.7 & 15 & 0.9 & 14 & 0.8 & 14 & 0.8 \\
\hline \multirow[t]{2}{*}{ Total } & 100 & 100 & & 100 & & 100 & \\
\hline & & (202 grains) & & (200 grains) & & (374 grains) & \\
\hline
\end{tabular}

Distribution of silver grains was calculated from EM autoradiographs of 15 absorptive cells at each time interval as described in Methods. Relative volumes of subcellular compartments were uniform at the three time intervals examined. Relative grain density refers to the percent of grains in a given compartment divided by the relative volume of that compartment (21). This provides a basis for comparing relative concentrations of radiolabel in various subcellular regions.

lysosomal vacuole, and over basolateral regions of epithelial cells. Some label also appeared in the lamina propria. After 60 and 120 min of continuous uptake, the general distribution of grains over the epithelium was comparable with that observed at 20 $\mathrm{min}$, but at $120 \mathrm{~min}$ the autoradiographic reaction over all areas, including lamina propria, increased significantly.

EM autoradiographs prepared after 20,60 , and $120 \mathrm{~min}$ of continuous ${ }^{125}$ I-EGF uptake were analyzed as described in Methods. Percentages of total grains associated with major cell regions, the relative volumes of these regions, and relative grain densities are shown in Table I. At all three time intervals, 10$14 \%$ of total grains were present over microvilli. Some of these grains were at the bases of microvilli (Fig. 5), and may have been associated with intermicrovillus membrane, a site of frequent coated pit formation. At all times, the highest numbers of grains (up to $44 \%$ at the 60 -min interval) and the highest grain densities were over the apical endocytic complex (Figs. 5 and 6), indicating a significant concentration of label in endosomal compartments (Table I). The close proximity of apical plasma membrane invaginations, smooth endocytic vesicles, coated vesicles, and labyrinthine tubular membranes within this area made more precise localization impossible, but many heavilylabeled areas contained only tubulocisternae (Fig. 6). Beneath the endocytic complex, the giant lysosomal vacuole contained $20-24 \%$ of the total grains at all times. Because the vacuole represents $\sim 45 \%$ of cell volume, however, radioactivity was not highly concentrated in this compartment. Some ${ }^{125}$ I-labeled molecules had apparently already been delivered to the basolateral side by $20 \mathrm{~min}$ : $26 \%$ of the grains were present in the basal regions of absorptive cells with $11 \%$ over basal cytoplasm and $15 \%$ associated with basolateral membranes (Fig. 7, $A$ and $B)$. Calculated grain densities in the basolateral membrane compartment were low (0.8-0.9) in spite of apparent association of many grains with this structure (Fig. $7 A$ ). This may be because the basolateral membrane "compartment" was defined for the purpose of grain counts as a wide, membrane-spanning corridor whose relative volume was much greater than the membrane itself, a single line source running through this corridor. ${ }^{125} \mathrm{I}$ EGF was sometimes found in the vicinity of coated vesicles and coated areas of basolateral membrane (Fig. $7 \mathrm{~B}$ ), but the resolution of the autoradiographic technique did not permit us to confirm the presence of EGF in these structures.

To confirm the existence of transepithelial transport vesicles in neonatal ileum, tissues were fixed and examined by EM 60 and 90 min after introduction of cationized ferritin (CF) into the lumen as described in reference 13. Small clusters of CF were contained in vesicles in the basal cytoplasm of absorptive cells and were also present along basolateral cell surfaces (Fig. 7 C).

Fate of ${ }^{125}$ I-EGF after uptake and transport. To determine to what degree EGF was altered or degraded during and after transepithelial transport, we analyzed radiolabeled molecules in the epithelium, underlying mucosa, blood, and liver by HPLC (Fig. 8) and SDS-PAGE autoradiography (Fig. 9). When stock radiolabeled EGF was chromatographed on a $\mathrm{C} 18$ reversed-phase column, radioactivity eluted in a single major peak at $48 \%$ acetonitrile, with a retention time of $17.5 \mathrm{~min}$ (Fig. $8 \mathrm{~A}$ ). Radiolabel in extracts of epithelium and mucosa eluted somewhat earlier than stock EGF. Epithelial extracts eluted in three distinct peaks, at $14,15.5$, and $16.5 \mathrm{~min}$ (Fig. $8 \mathrm{~B}$ ). Mucosal radioactivity eluted in a broad peak over a similar range, fróm 14 to $18 \mathrm{~min}$ (Fig. 8 $C)$. In addition, a portion of the radioactivity extracted from mucosa eluted in much earlier peaks, at 5 and $6 \mathrm{~min}$. In contrast, radioactivity in serum and liver eluted principally in the early peak at $5 \mathrm{~min}$, and a portion of label in serum also eluted in a smaller peak at 6 min. Free ${ }^{125} I$ eluted entirely in a peak at 5 min, in the presence or absence of serum.

SDS-PAGE and autoradiography of the same tissue extracts (epithelium, mucosa, serum, and liver) obtained after $30 \mathrm{~min}$ of continuous ${ }^{125}$ I-EGF uptake, is shown in Fig. 9. Stock samples of ${ }^{125}$ I-EGF electrophoresed in a diffuse band with molecular weight in the range of $6-12 \mathrm{kD}$, as previously reported (24). 


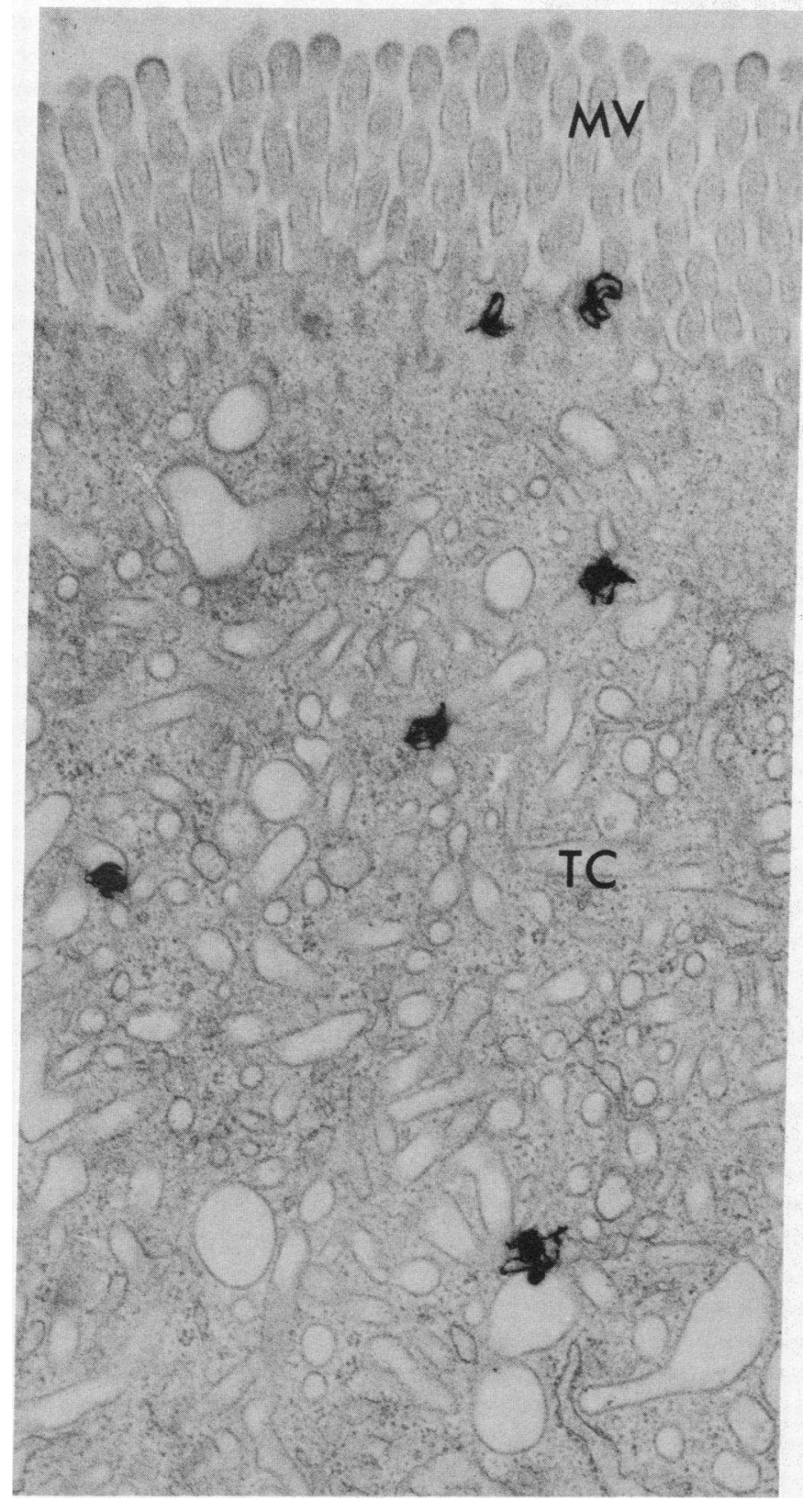

Figure 5. EM autoradiograph of the apical region of an ileal absorptive cell $20 \mathrm{~min}$ after intraluminal injection of ${ }^{125}$ I-EGF. Silver grains are present over the bases of microvilli $(M V)$ and the tubulocisternae (TC) of the endocytic complex. Although label was concentrated in these regions, deeper regions of the cell were also labeled (Table I).

Radioactivity in extracts of epithelium and mucosa migrated slightly below the 6-kD form of EGF but well above the solvent front, suggesting a slight modification in the molecular size of the probe. No radiolabeled molecules were detected by SDSPAGE of serum or liver.

\section{Discussion}

Several lines of evidence indicate that EGF is transported from the lumen to the blood in the suckling rat gastrointestinal tract.
${ }^{125}$ I-EGF fed orally to suckling rats was recovered as immunoreactive, labeled molecules of a size large enough to be excluded from Sephadex G25 columns in various tissues including intestinal wall, blood, and liver (5). In other studies, orally administered EGF promoted growth of intestinal tissues of adult (25) and suckling rats (26). Systemically administered EGF is trophic for gastrointestinal tissues (27-30) and EGF receptors have been demonstrated on epithelial cells isolated from both adult (31, 32 ) and suckling (16) rodent intestines. EGF receptors were reported present in equal numbers on both crypt and villus cells isolated from suckling rats (16), but their distribution along the length of the small intestine or their exact location on apical or basolateral surfaces was not ascertained. In our studies using isolated villus epithelial sheets, ${ }^{125}$ I-EGF bound to basolateral but also to apical membranes of ileal villus cells. In vivo, ${ }^{125} \mathrm{I}$ EGF was taken up from the lumen by villus cells, but little or no binding or uptake of luminal ${ }^{125}$ I-EGF was observed in crypts. This suggests that EGF receptors on crypt cells may be located primarily on basolateral membranes, perhaps functioning to promote proliferation of the epithelium itself. Subcellular fractions of rat small intestinal villus cells, enriched in microvillus membranes, were recently found to contain specific EGF-binding activity (15), indicating that villus EGF receptors are located at least in part on luminal membranes and thus would be available to bind EGF in milk. By EM autoradiography, we have now shown that in the ileum, EGF binds specifically not only to microvillus membranes but also to the invaginated apical membrane domains previously shown to be involved in endocytosis of membrane-bound luminal molecules $(13,33)$. It should be emphasized that the goal of this study was to elucidate transepithelial transport systems in the specialized absorptive cells of suckling rat ileum, and thus only ileum was examined. The possibility remains that luminal EGF receptors are also present on duodenal and jejunal cells and that endocytosis and transcytosis of EGF occurs in proximal as well as distal small intestine.

The absorptive epithelium of the entire rat small intestine is highly endocytic during the suckling period, the first 3 wk after birth. During this time, proteolytic enzyme activity in the intestinal lumen is low (34), so that little degradation of milk occurs in the lumen of the gastrointestinal tract. In absorptive cells of proximal small intestine, specific receptors for the Fc portion of IgG mediate uptake and transepithelial transport of intact maternal antibodies from milk to the circulation of the young $(8,9)$. Undigested milk then passes to the ileum where it is endocytosed and degraded intracellularly. Ileal absorptive cells take up luminal contents into a highly developed complex of endosomal compartments and transport them to a giant lysosomal vacuole for degradation (10-12). Degradation products are presumed to diffuse across vacuolar and cell membranes, and hence into the neonatal circulation. Although this process was generally thought to be nonselective, directing all components of milk along a single lysosome-directed path, recent studies from this laboratory demonstrated that the tubulocisternal system is involved only in uptake of membrane-bound molecules (including CF and certain lectins) and that soluble molecules such as native ferritin are directed by the ileal cell into separate, vesicular prelysosomal compartments (13). The observation that small amounts of membrane-bound (but not soluble) tracers were transported to basolateral cell surfaces suggested that ileal cells, like their counterparts in jejunum, might sort certain membrane-bound milk molecules, perhaps bound to specific 


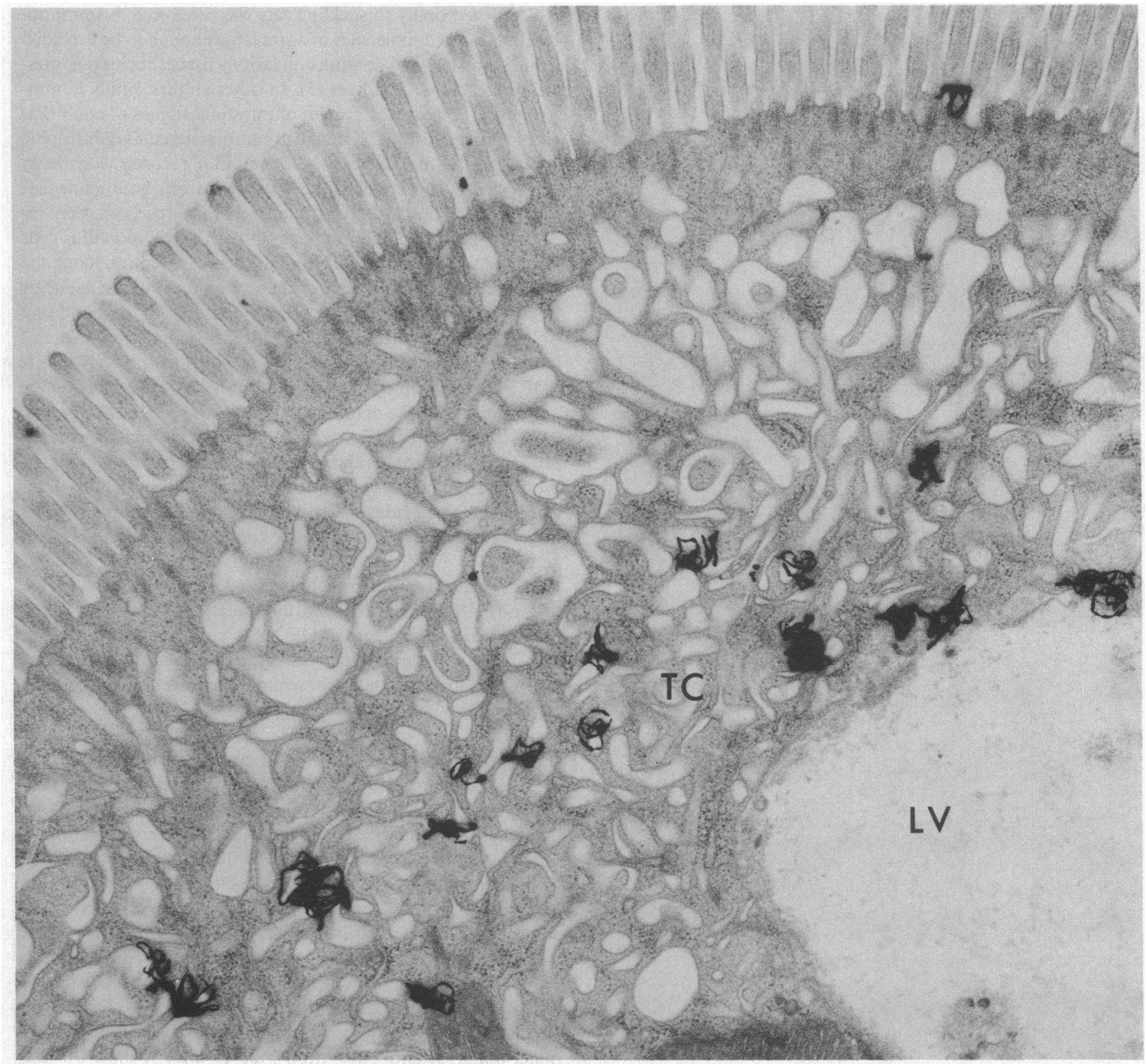

Figure 6. EM autoradiograph of the apical region of an ileal absorptive cell $60 \mathrm{~min}$ after intraluminal injection of ${ }^{125}$ I-EGF. Although label was present throughout the endocytic pathway, in lysosomal vacuole $(L V)$ and basolateral regions, it was most concentrated in apical tubulocisternae $(T C)$.

receptors, out of the lysosome-directed pathway for transepithelial transport. We have now shown that the physiologic milk peptide EGF may be selectively transcytosed via this pathway.

The doses of luminal EGF used in this study were well in excess of the levels present in rat milk, and presumably also far higher than the total binding capacity of ileal cell EGF receptors. To detect uptake and transport by EM autoradiography, we applied up to $1 \mu \mathrm{g} / \mathrm{ml}$ to an epithelium that normally would be exposed to milk concentrations of only $\sim 40 \mathrm{ng} / \mathrm{ml}$ (5). Under these conditions, nonspecific binding of the peptide to cell membranes may occur (16) and in addition, significant amounts of soluble EGF would be expected to enter the fluid-phase uptake pathway. Nonspecific uptake by both of these mechanisms could have contributed to lysosomal degradation and subsequent diffusion of free ${ }^{125} I$ and labeled amino acids into the mucosa and blood, measured in this study as radiolabel not precipitable by TCA, and label appearing very early during elution from the reversed-phase HPLC column. Previous tracer studies indicated that the giant lysosome receives all of the proteins present in fluid-phase vesicles as well as most of the adsorbed molecules that enter the tubulocisternae (13). The proportions of EGF that reached the lysosome via these two pathways could not be determined in our EM autoradiographs. In any case, lysosomal degradation and loss of label would account for the lack of increase in relative grain density over lysosomes between 20 min and $2 \mathrm{~h}$ of continuous ${ }^{125} \mathrm{I}$-EGF uptake. Lysosome membranes 


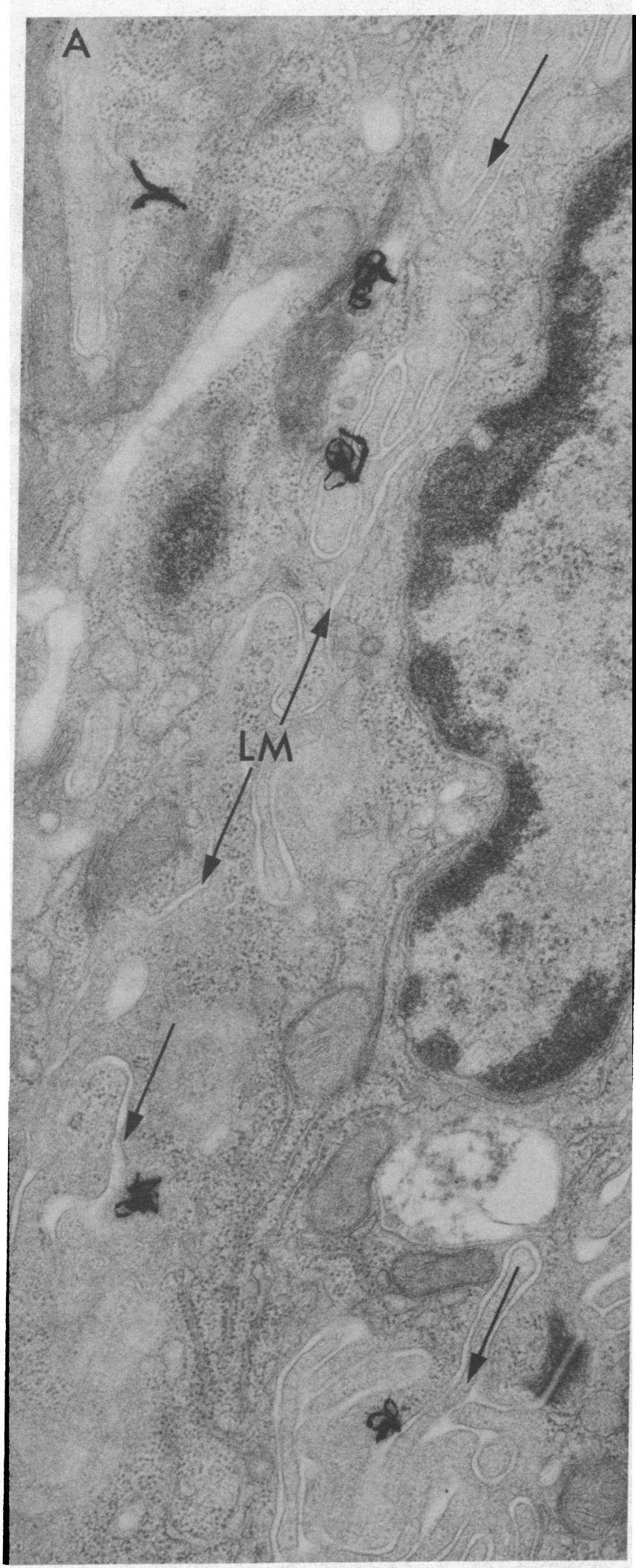

Figure 7. Lateral and basal surfaces of absorptive cells, 120 min after injection of ${ }^{125}$ I-EGF $(A$ and $B)$ or 90 min after injection of CF $(C)$ into ileal loops. $(A)$ Silver grains are associated with highly interdigitated surfaces of adjacent absorptive cells. Parallel lateral plasma
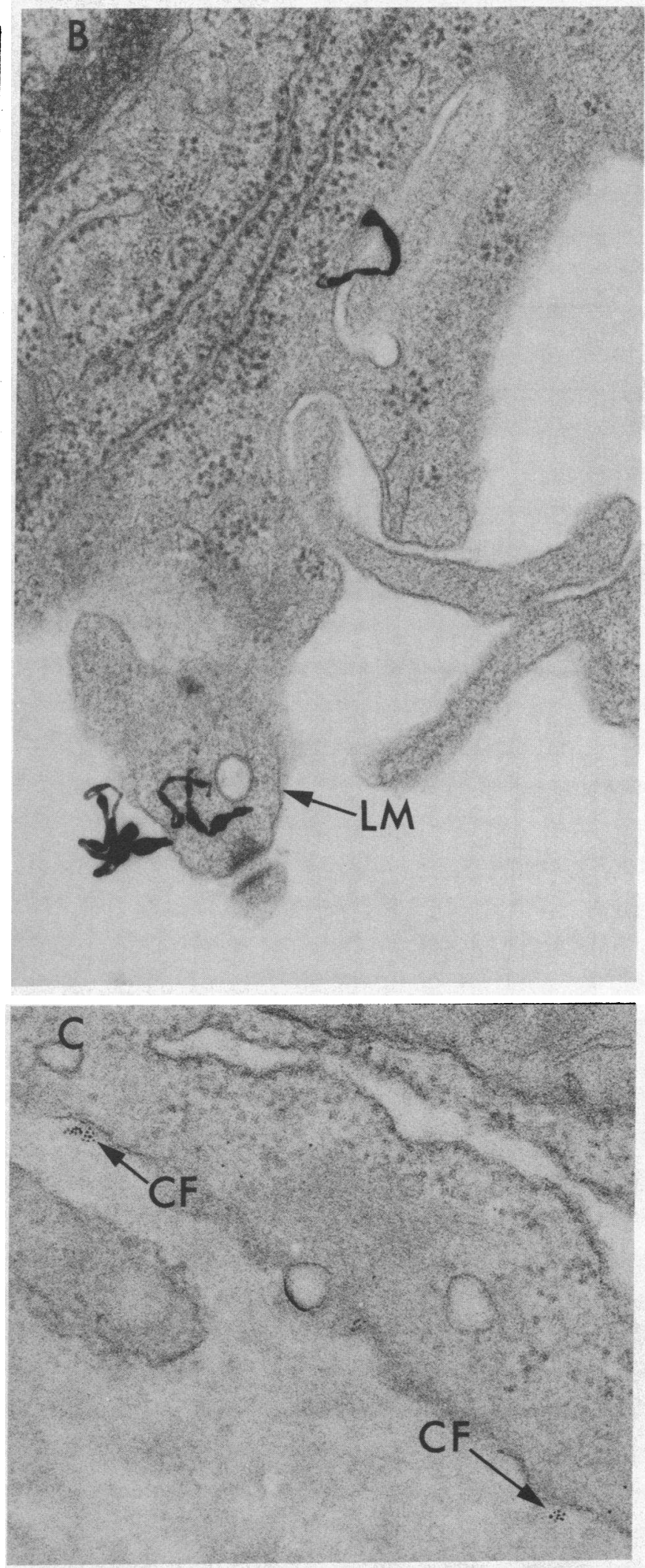

membranes $(L M)$ are indicated by arrows. (B) Silver grains are also associated with noninterdigitated regions of lateral cell membrane $(L M)$. (C) Small clusters of CF appear along basolateral membranes after 60-90 min of uptake from the lumen. 

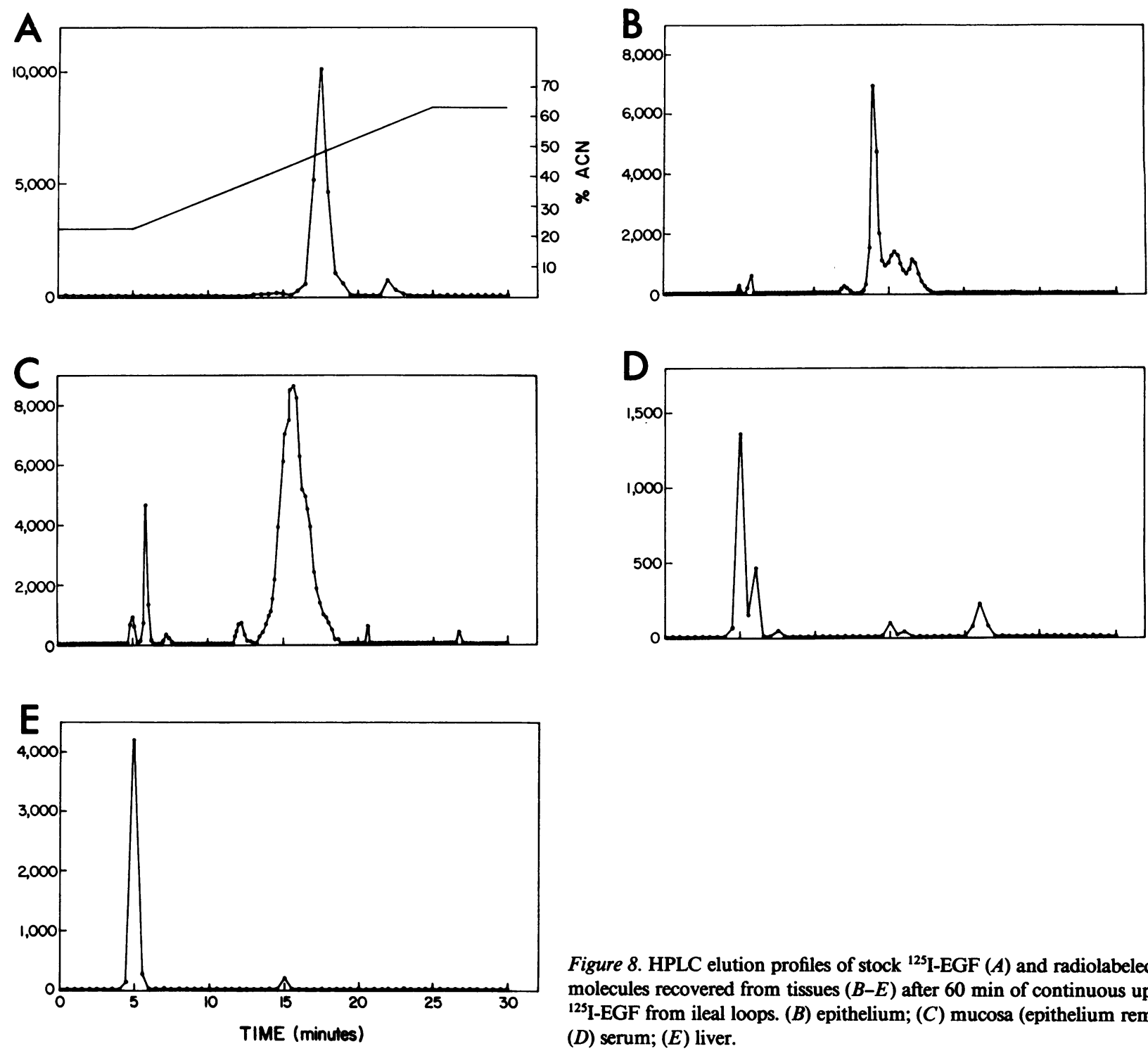

Figure 8. HPLC elution profiles of stock ${ }^{125}$ I-EGF $(A)$ and radiolabeled molecules recovered from tissues $(B-E)$ after $60 \mathrm{~min}$ of continuous uptake of ${ }^{125}$ I-EGF from ileal loops. $(B)$ epithelium; $(C)$ mucosa (epithelium removed); $(D)$ serum; $(E)$ liver.

are generally permeable to amino acids but not to dipeptides or larger molecules (35) so EGF and large degradation products should not diffuse from lysosomes into the cytoplasm or lamina

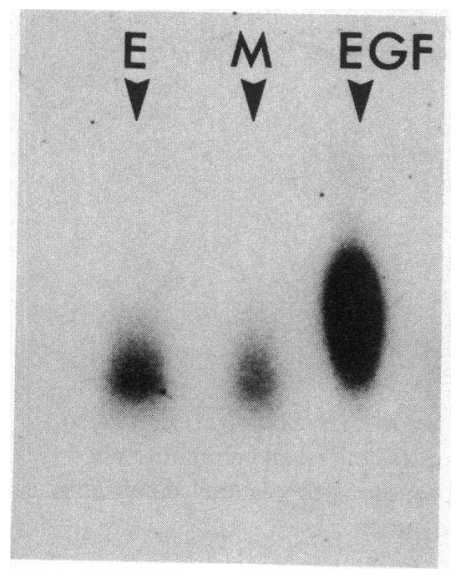

propria. Free ${ }^{125}$ I and radiolabeled amino acids released by lysosomal digestion would be lost from tissues during fixation and embedment before autoradiography, and should not have contributed to the autoradiographic reaction in basal cell regions and lamina propria.

Although the autoradiographic and biochemical data obtained in this study are consistent with transport of the major portion of endocytosed EGF to the giant lysosomal vacuole and subsequent degradation, they are also consistent with entry of a small amount of intact EGF into a transepithelial transport pathway. Transepithelial transport of EGF has been demonstrated in hepatocytes and was determined to depend in part on binding of the peptide to hepatocyte membranes (36). In ileal cells, high grain densities observed over apical tubulocisternae suggest that a significant amount of EGF was initially taken up in membrane-bound form. The site at which EGF enters the transepithelial pathway could not be ascertained, however. Small amounts of EGF could have been sequestered in transepithelial transport vesicles formed directly from clathrin-coated regions of apical membrane, or alternatively could have been withdrawn 
from the tubulocisternae, where clathrin-coated pits are also frequently observed. Transcytosis was due at least in part to binding of ${ }^{125} \mathrm{I}$-EGF to specific receptors, because inclusion of 1,000 -fold unlabeled EGF resulted in a $44 \%$ decrease in radiolabel in basal regions of epithelial cells as visualized by autoradiography and a $38 \%$ reduction in TCA precipitable serum radiolabel. In addition, however, a significant amount of ${ }^{125}$ I-EGF appeared to cross the epithelium in a nonspecific fashion. The possible existence of a nonselective, fluid-phase transepithelial transport pathway, comparable with that documented in hepatocytes (37) has not been ruled out. We consider it unlikely that ileal transport of EGF was due simply to fluid-phase vesicles, however, because no transepithelial transport was detected in previous studies in which soluble proteins were applied to the ileal mucosa in concentrations as high as 25 and $10 \mathrm{mg} / \mathrm{ml}$ (native ferritin, references 10 and 13 ) or $20 \mathrm{mg} / \mathrm{ml}$ (horseradish peroxidase, reference 11 ). It seems more likely that honspecific adherence of ${ }^{125}$ I-EGF was responsible for a portion of the labeled peptide that entered apical tubulocisternae and transepithelial transport vesicles because nonphysiological, adherent tracers such as cationized ferritin were seen to follow the same route.

Previous investigators demonstrated that a portion of orally fed EGF that is transported across the gastrointestinal epithelium retains immunoreactivity and, at least in mucosa, retains its ability to bind to EGF receptors (5). Although the isoelectric point of orally fed ${ }^{125}$ I-EGF was reported to shift in the lumen and during uptake, some of the transported peptide recovered from blood and liver was considered structurally intact on the basis of its elution in the void volume of Sephadex G25 gel filtration columns (5). In preliminary intestinal uptake studies, however, we observed that radiolabeled molecules recovered from serum and liver eluted from Sephadex G50 columns at molecular weights higher than that of standard EGF, suggesting noncovalent binding of labeled EGF or its fragments to other proteins. In parallel studies on uptake of ${ }^{125}$ I-NGF, we showed that degradation products of ${ }^{125} \mathrm{I}-\mathrm{NGF}$ (but not intact ${ }^{125} \mathrm{I}-\mathrm{NGF}$ ) were recovered from liver and brain noncovalently bound to larger molecules and that such binding accounted for all radioactivity in the void volume of such columns (14). In the present study, we therefore chose to examine transported EGF radiolabel under dissociating conditions: reversed-phase HPLC in strong acid and organic solvents, and SDS-PAGE.

Radiolabeled molecules in extracts of epithelium and mucosa were eluted from C18 HPLC columns at positions slightly different from the elution position of standard EGF, indicating that the charge or hydrophobicity of the peptide was modified during transepithelial transport. On SDS gels, radiolabeled peptides from epithelium and mucosa appeared as bands migrating somewhat more rapidly than the broad band representing monomeric and dimeric forms of standard radiolabeled EGF (24), and therefore slightly reduced in molecular weight. The magnitude of this reduction could not be determined in the gel system used. Internalization of EGF in fibroblast target cells has been reported to result in sequential changes (38-41) beginning with a rapid, minor modification that appears to occur after entry into an acidic compartment $(39,40)$ but before entry into lysosomes $(40,41)$. This early modification, consistent with removal of one or more amino acids from the carboxy terminus $(38,41)$, did not result in loss of receptor binding activity (40, 41 ) or immunoreactivity (41). Subsequent stages of modification and breakdown required lysosomal enzyme activity and resulted in loss of receptor binding $(40,41)$. Our data suggest that EGF also undergoes limited cleavage during transepithelial transport. Such changes may occur rapidly, perhaps upon entry of EGF into an apical endosomal compartment in ileal cells, because no unmodified EGF was detected in epithelial extracts. Further studies are needed to map the exact transcellular route of EGF and to determine whether EGF remains receptor-associated along this pathway.

Radiolabel in serum and liver extracts, in contrast, eluted as markedly different positions from those of both "standard" and "modified" EGF by HPLC and were not detected on SDS gels, suggesting that extensive degradation had occurred. Serum EGF is known to be rapidly and efficiently bound by hepatocyte receptors (42); as much as $90 \%$ of an injected dose was cleared during a single pass through the liver (43). In this study, the mucosal EGF that entered the bloodstream must have been rapidly removed and degraded in liver and perhaps in other target tissues, because no accumulation of intact or modified peptide could be detected in serum at any point during uptake. In contrast to our data, Thornburg et al. (5) detected labeled immunoreactive peptides in blood and liver after oral feeding of ${ }^{125} \mathrm{I}$ EGF to suckling rats. Our HPLC and SDS-PAGE results do not rule out the possibility that immunoreactive fragments of EGF persisted in blood and liver after ileal uptake.

Despite modifications during its uptake from the lumen, the EGF derived from milk that accumulates in the mucosa may be biologically active (5) and could bind to local receptors such as those on crypt cell basolateral membranes to stimulate cell proliferation in the suckling intestine. This hypothesis is supported by the observation that feeding of EGF-supplemented formula to suckling rats induced intestinal growth but had no effect on stomach or liver (25). In separate studies, we have demonstrated that nerve growth factor, a peptide also present in milk, is transported across the ileal epithelium of suckling rats but is not cleared as rapidly from the blood and thus could potentially influence the development of distant neural tissues as well as enteric neurons (14). The influence of milk EGF, in contrast, may be limited to the intestinal mucosa because rapid hepatic clearance would prevent the delivery of biologically active peptide to distant sites.

\section{Acknowledgments}

The authors wish to acknowledge the expert technical assistance of Linda Owen, Jayne Bernanke, and Patrick Bilbo.

This work was supported by National Institutes of Health grants HD-17557 (Dr. Neutra), NS-19100 (Dr. Murphy), fellowship AM-06931 (Dr. Gonnella), and Digestive Disease Center grant AM-34854 to Harvard Medical School. Dr. Siminoski was supported by a fellowship from the Alberta Heritage Foundation for Medical Research.

\section{References}

1. Carpenter, G., and S. Cohen. 1979. Epidermal growth factor. Annu. Rev. Biochem. 48:193-216.

2. Gospodarowicz, D. 1981. Epidermal and nerve growth factors in mammalian development. Annu. Rev. Physiol. 43:251-263.

3. Beardmore, J. M., and R. C. Richards. 1983. Concentrations of epidermal growth factor in mouse milk throughout lactation. J. Endocrinol. 96:287-292. 
4. Greuters, A., J. Alm, J. Lakshmanan, and D. A. Fisher. 1985. Epidermal growth factor in mouse milk during early lactation: lack of dependency on submandibular glands. Pediatr. Res. 19:853-856.

5. Thornburg, W., L. Matrisian, B. Magun, and O. Koldovsky. 1984. Gastrointestinal absorption of epidermal growth factor in suckling rats. Am. J. Physiol. 246:G80-G85.

6. Carpenter, G. 1980. Epidermal growth factor is a major growthpromoting agent in human milk. Science (Wash. DC). 210:198-199:

7. Moran, J. R., M. E. Courtney, D. N. Orth, R. Vaughan, S. Coy, C. D. Mount, B. J. Sherell, and H. L. Greene. 1983. Epidermal growth factor in human milk: daily production and diurnal variation during early lactation in mothers delivering at term and at premature gestation. J. Pediatr. 103:402-405.

8. Rodewald, R. 1980. Distribution of immunoglobulin G receptors in the small intestine of the young rat. J. Cell Biol. 85:18-32.

9. Abrahamson, D., and R. Rodewald. 1981. Evidence for the sorting of endocytic vesicle contents during the receptor-mediated transport of IgG across the newborn rat intestine. J. Cell Biol. 91:270-280.

10. Kraehenbuhl, J.-P., E. Gloor, and B. Blanc. 1967. Resorption intestinale de la ferritine chez deux especes animales aux possibilites d'absorption proteique neonatale differentes. Z. Zellforsch. Mikrosk. Anat. 76:170-186.

11. Graney, D. O. 1968. The uptake of ferritin by ileal absorptive cells in suckling rats: an electron microscope study. Am. J. Anat. 123: 227-254.

12. Cornell, R., and H. A. Padykula. 1969. A cytological study of intestinal absorption in the suckling rat. Am. J. Anat. 125:291-316.

13. Gonnella, P. A., and M. R. Neutra. 1984. Membrane-bound and fluid-phase macromolecules enter separate prelysosomal compartments in absorptive cells of suckling rat ileum. J. Cell Biol. 99:909-917.

14. Siminoski, K., P. Gonnella, J: Bernanke, L. Owen, M. Neutra, and R. A. Murphy. 1986. Uptake and transepithelial transport of nerve growth factor in suckling rat ileum. J. Cell Biol. 103:1979-1990.

15. Thompson, J. F. 1986. Evidence for specific epidermal growth factor (EGF) receptors on fetal, suckling and adult rat intestinal microvillus membranes (MVM). Gastroenterology. 90:1664. (Abstr.)

16. Rao, R. K., W. Thornburg, M. Korc, L. M. Matrisian, B. E. Magun, and O. Koldovsky. 1986. Processing of epidermal growth factor by suckling and adult rat intestinal cells. Am. J. Physiol. 250:G850G855.

17. Savage, C. R., and S. Cohen. 1972. Epidermal growth factor and a new derivative. J. Biol. Chem. 247:7609-7611.

18. Caro, L. G., and R. P. van Tubergen. 1962. High-resolution autoradiography. I. Methods. J. Cell Biol. 15:173-178.

19. Salpeter, M. M., F. A. McHenry, and E. E. Salpeter. 1978. Resolution in electron microscope autoradiography. IV. Application to analysis of autoradiograms. J. Cell Biol: 76:127-145.

20. Weibel, E. R., and R. P. Bolender. 1975. Stereological techniques for electron microscopic morphometry. In Principles and Techniques of Electron Microscopy. M. A. Hayat, editor. Van Nostrand Reinhold, New York. 239-296.

21. Salpeter, M. M., and F. A. McHenry. 1973. Electron microscope autoradiography: analysis of autoradiograms. In Advanced Techniques in Biological Electron Microscopy. J. K. Koehler, editor. Springer Verlag New York. 113-152.

22. Bjerknes, M., and H. Cheng. 1981. Methods for the isolation of intact epithelium from the mouse intestine. Anat. Rec. 199:565-574.

23. Phillips, T. E., T. H. Phillips, and M. R. Neutra. 1984. Regulation of intestinal goblet cell secretion. III. Isolated intestinal epithelium. Am. J. Physiol. 247:G674-G681.

24. Bridgen, P. 1981. Anomalous behavior of EGF on SDS-PAGE. Bethesda Research Laboratories Biologique. 1:1.
25. Ulshen, M. H., L. Lyn-Cook, and R. Raasch. 1985. Intraluminal administration of epidermal growth factor (EGF) stimulates mucosal proliferation in the small bowel. Gastroenterology. 88:1621.

26. Berseth, C. L. 1985. EGF-mediated, breâst milk-enhanced intestinal growth in neonatal rats. Pediatr. Res. 19:213A. (Abstr.)

27. Scheving, L. A., Y. C. Yeh, T, H. Tsai, and L. E. Scheving. 1980 Circadian phase-dependent stimulatory effects of epidermal growth factor on deoxyribonucleic acid synthesis in the duodenum, jejunum, ileum, cecum, and rectum of the adult male mouse. Endocrinology. 106:14981503.

28. Malo, C., and D. Menard. 1982. Influence of epidermal growth factor on the development of the suckling mouse intestinal mucosa. Gastroenterology. 83:28-35.

29. Oka, Y., F. K. Ghishan, H. L. Greene, and D. N. Orth. 1983 Effect of mouse epidermal growth factor/urogastrone on the functional maturation of rat intestine. Endocrinology. 112:940-944.

30. Dembinski, A. B., and L. R. Johnson. 1985. Effect of epidermal growth factor on the development of rat gastric mucosa. Endocrinology. 116:90-94.

31. Forgue-LaFitte, M. E., M. Laburthe, M. C. Chamblier, A. J. Moody, and G. Rosselin. 1980. Demonstration of specific receptors for EGF-urogastrone in isolated rat intestinal epithelial cells. FEBS (Fed. Eur. Biochem. Soc.) Lett. 114:243-246.

32. Gallo-Payet, N., and J. S. Hugon. 1985. Epidermal growth factor receptors in isolated adult mouse intestinal cells: studies in vivo and in organ culture. Endocrinology. 116:194-201.

33. Gonnella, P. G., and M. R. Neutra. 1985. Glycoconjugate distribution and mobility on absorptive cell membranes of suckling rat ileum in vivo. Anat. Rec. 213:520-528.

34. Henning, S. J. 1979. Biochemistry of intestinal development. Environ. Health Perspect. 33:9-16.

35. Cohn, Z. A., and B. A. Ehrenreich. 1969. The uptake, storage, and intracellular hydrolysis of carbohydrates by macrophages. J. Exp. Med. 129:201-225.

36. Burwen, S. J., M. E. Barker, I. S. Goldman, G. T. Hradek, S. E. Raper, and A. L. Jones. 1984. Transport of epidermal growth factor by rat liver: evidence for a nonlysosomal pathway. J. Cell Biol. 99:12591265 .

37. Lake, J. R., V. Licko, R. W. Van Dyke, and B. F. Scharschmidt. 1985. Biliary secretion of fluid-phase markers by the isolated perfused rat liver. J. Clin. Invest. 76:676-684.

38. Planck, S. R., J. S. Finch, and B. E. Magun. 1984. Intracellular processing of epidermal growth factor. II. Intracellular cleavage of the $\mathrm{COOH}$-terminal region of ${ }^{125} \mathrm{I}$-epidermal growth factor. J. Biol. Chem. 259:3053-3057.

39. Matrisian, L. M., S. R. Planck, and B. E. Magun. 1984. Intracellular processing of epidermal growth factor. I. Acidification of ${ }^{125} \mathrm{I}$ epidermal growth factor in intracellular organelles. J. Biol. Chem. 259: 3047-3052.

40. Wiley, H. S., W. Van Nostrand, D. N. McKinley, and D. Cunningham. 1985. Intracellular processing of epidermal growth factor and its effect on ligand-receptor interactions. J. Biol. Chem. 260:5290-5295.

41. Schaudies, R. P., and C. R. Savage, Jr. 1986. Intracellular modification of ${ }^{125} \mathrm{I}$-labeled epidermal growth factor by normal human foreskin fibroblasts. Endocrinology. 118:875-882.

42. Dunn, W. A., T. P. Connolly, and A. L. Hubbard. 1986. Receptor mediated endocytosis of epidermal growth factor by rat hepatocytes: receptor pathway. J. Cell Biol. 102:24-36.

43. St. Hilaire, R. J., G. T. Hradek, and A. L. Jones. 1982. Hepatic sequestration and biliary secretion of epidermal growth factor (EGF): evidence for a high capacity uptake system. Proc. Natl. Acad. Sci. USA. 80:3797-380i 